\title{
THE LANGUAGE OF THE CLEOPATRA MS. OF THE ANCREN RIWLE.
}

§ 1. The Cleopatra Ms. (Cleopatra C. VI) is included, with the Ms. (Nero A. XIV) from which Morton's text is taken, in the Cottonian Collection of the British Museum. My first intention was to collate Morton's text with the original but, finding a pupil of Prof. Napier already far advanced in that work, I turned my attention to the language of Cleopatra. Since my time was limited, it was a choice between a thorough investigation of part of the Ms., or a hasty examination of the whole. I have chosen the former alternative.

The following examples are intended to show that the Cleopatra Ms. differs in dialect from Nero, and that where it differs it coincides in a marked degree with the language of the Katherine Group.

$\S 2 . \quad$ OE. $\breve{e}$ (Merc. Kent. $e$ ). The normal representative of this sound in the Katherine Group (K. G.) is $e$, with occasional ca spellings (cp. Stodte, Katherine-Gruppe, Gött. 1896 \& 3); after $w, e$ or $e a$ preserved (cp. Morsbach me. Gr. $\S \S 100,101$ ).

Cleopatra and Nero have alike normally e: efter $\left.{ }^{1}\right) 62,26$; 56,$12 ; 14,1$ etc.; hefde 66,$4 ; 8,21$; hefdest 38,20 ; pet 28,6 ; ed 18, 23; 18, 27; 18, 26 (Nero et in each case); etfleo 50, 19; feste 34, 12 (Nero ueste); ifestned 62, 24 (N. ivestned); hweder 70, 12 (cp. Morsbach as above $\S 100$ ).

In their treatment of the sound after $w$ Cleopatra and Nero differ, and Cleop. agrees with K. G. Thus Cleop. has generally $e$ after $w$ : wes 58,3 and always; hwet 12,9 and in the great majority of instances; but hwat 72. 26 and in a few instances. Water occurs in my material once P. 72, 18 also warre 66, 23 (OE. war) but both of these are found also in K. G. (cp. Stodte P. 14, 3).

Nero has $a$ in all these instances.

1) All references are to Morton's text, the Cleo. examples are those found at the corresponding place in that Ms. 
$\S 3$. OE. $\bar{a}$. The normal symbol in K. G. is a, occasional $o$ and $o a$ spellings (cp. Stodte $\S 9$ ).

Cleop. has $a$ in nearly every case, $o$ rarely. Ex.: gað 44, 14; forgan 8,$1 ;$ gan 12,$20 ;$ stan 56,7 ; grindstanes 70,$15 ;$ fa 62,5 : vacnesse 66,6 ; wac 12,19 ; swa 56,15 ; 26,21 ; gast 28,3 ; mare 54,$7 ; 54,10 ;$ ma 42,$16 ; 62,5 ; 30,7$; hali 22,$8 ; 26,17 ; 26,10$; 12,16 etc.: are 32,$8 ; 26,18$; bihaten 8,$20 ; 28,8$; ihaten 62,19 ; wat 62,$25 ; 54,7$; brade 54,15 ; ladlukest 66,22 ; saule 14,5 ; 26,$20 ; 38,10 ; 50,19$; lauerd 28,$19 ; 30,18 ; 28,8 ; 32,7 ; 30,2$; 44,$22 ; 56,18 ; 58,18 ; 62,21 ; 62,15 ; 66,26 ;$ clades 12,$6 ; 14,22$; hwase 60,$25 ; 42,19 ; 42,25 ; 46,12$ etc. twa 70,15; hal 38,14; gastliche 38,$28 ; 40,9 ; 14,12 ;$ ba 18,$21 ; 54,10 ;$ baðe 46,9 ; lare 28,$23 ;$ naut 6,$26 ; 12,12 ; 12,3 ; 46,11$ etc.; an 56,6; 22,19; 16,7 ; anan 22,$7 ; 42,20$; ane 12,11 ; annesse 12,$7 ; 12,6 ; 12,6$; anlicnesse 18,15 ; nane 70,20 ; nan 26,$8 ; 70,22 ; 68,16 ; 68,4$.

Nero has $o$ in all these instances except in 54,15 where the spelling is broid.

In a few cases Cleo. has 0 : louerd 12, 20; forhoten 8,5 .

$\S$ 4. OE. $\bar{a}(\bar{e})$. a) W.S. Angl. $\overline{\bar{e}}$ (Gmc. $a i-i)$. K. G. has $e$ and $e a$ spellings, both frequent (cp. Stodte $\S 10, a$ ).

Cleo. has also $e$ and $e a$, the latter predominating (once $e o$ ), while Nero has $e$ in the majority of instances, $e a$ rarely.

Examples (I) Cleop. $e$ or ee : eni 8,15 ; euer 52,$12 ; 12,9$; lees 30,7 ; 42,16; lesse 56,21 ; punwreste 68,9 ; imene 12,8 ; techen 50,15 ; hwete 70,$13 ; 70,14 ;$ hestes 28,$17 ; 8,9$; flesliche 38,10 ; flesch 38,$5 ; 6,9$; flech 38,8 ; flesc 8,1 ; clense 38,9 ; mest 30,$6 ; 34,14$; fleschliche 58, 22; heste 58, 20; 6, 21; 6, 1; 6, 25.

Nero has $e$ in all corresponding instances: eni, euer, les etc.

(II) Cleo. ea : neauer 6,$22 ; 60,8 ; 70,17 ; 56,21 ; 44,7 ; 38,8$; 38,$1 ;$ eaner 6,$2 ; 6,3 ; 4,16 ; 2,13 ; 16,10 ; 20,4$ etc.; eaue 68,18 ; leafde 70,13 ; leaue 38,2 ; ear 10,$15 ; 12,2 ; 72,4 ; 36,11 ; 36,10$; 20,$10 ; 20,18$; earest 10,$20 ; 60,19 ; 14,3 ; 64,15 ; 14,26$ etc. eareste 22,$21 ; 8,19 ; 18,11$; areared 72,5 ; learen 14,25 ; leasted 20,25; leasten 20,20; lead 40,1; heale 38,14; heal (imp.) 38, 15; dealen 38,24 ; ich deale 28,4 ; canes 70,1 ; teache 66,20 ; cleane 38,13 ; todeale 12,26; ileared 64, 23; learen 64, 25; leared 64, 25.

Nero $e$ : neuer, euer, lefde etc., $e$ in all above instances.

(III) Cleo. e, Nero ea: C. hele sb., N. heale 70, 18; C. lesse, N. leasse 6,$14 ;$ C. clene. N. cleane 4, 21; 10, 2.

(IV) Cleo. eo, N. e: C. leoste, N. leste 50, 19. 
b) WS. $\hat{a}$, Angl. Kt. $\bar{e}$ (WGmc. $\bar{a}$ and $a i$ ). K. G. $e$ usual spelling, ea rare, eo twice (cp. Stodte $\S 10, b$ ).

Nero and Cleo. employ $e$ generally, each has $e a$ in a few rare instances, Nero uses eo occasionally.

Here Nero and Cleo. agree with each other and with K. G. There is no evidence to show that WS. $\hat{\theta}$ was the original sound; in Cleo. at least where WS., Angl. $\bar{P}$ is so frequently written $c a$, we should expect frequent $e a$ spellings here also, if the original sound had been 'wide'.

The examples are as follows: Cleo. leten 8,4 ; offered 8,16 ; per 12,$20 ; 12,21 ; 12,20 ; 14,22 ; 14,23 ; 18,22 ; 26,8 ; 30,7$; 32,$3 ; 44,15 ; 60,20 ;$ dede 38,16 ; ich drede 38,15 ; euensong 22,7 ; 70,8 etc.; slepe ich 28,5 ; unimete 40,13 ; leted 42,30 ; redunge 44,$4 ;$ mel 44,$15 ; 20,26$; sumdel 20,$8 ; 18,20 ;$ seli 60,$25 ; 68,14$; 68,10 ; neddre 66,4 ; to lede 72,11 ; letunge 14, 23; greize 12,4 ; anrednesse 12, 5; slepen 46, 11; dede 62, 26; dred (Imp.) 58, 23; zer 70,$5 ; 54,10$; weren 72,12 etc.; were 70,$12 ; 38,9 ; 14,10$; ived 66,5 ; red 66,20 ; reden 44,8 ; wepnes 60,15 ; wepmones 58,6 ; wepnen 60,16 ; dred sb. 12, 19; 54, 13.

Nero has $e$ in all corresponding examples. As regards the spelling ea, Cleo. has pear 34,17; 78, 2, Nero per, both have ea in read 6,20, Nero has read 6, 16 where Cleo. has $e$. Cleo. has no instance of the eo spelling but Nero has weopmen 56, 24 ; 10,$22 ; 70,24$.

$\S 5$. WS. $e a+h, h+$ cons. K. G. generally $a$ (cp. Stodte $\S 20$ ).

Cleo. shows the Mercian development in: achtude 14, 19 (Nero eihtude); achte 12, 26 (Nero eihte); machte subs. 58, 10 (Nero muhte); machten 62,16 (Nero muhten); machte pret. 70,12 (Nero muhte); monslacht 56, 17 (Nero monsleiht); machte subs. 76, 20 (Nero mihte).

In one example the $i$-mutated Saxon form occurs, michte 76,27 , but this is found also in K. G. (cp. Stodte $\S 21$ ).

$\S 6$. Angl., Kt. $a$-umlant of $\check{e}$. K. G. has frequent eo forms, $e$ also occurs.

Cleo. agrees here with K. G. and differs considerably from Nero.

Cleo. to eoten 54, 3 (Nero to ctene); C. ze eoted 20, 26 (N. ze eteð); C. beoreð Imp. 68, 17 (N. bereð); C. ha beoreð 104, 24 (N. bereð); C. zeouen Inf. 92, 17 (N. to ziuen); C. to zeoue 106, 20 
(N. ziuen); C. beore 1) opt. 90,7 (N. bere); C. walde steoke 62, 15 (N. steken); C. bisteoken 62,16 (N. bisteken); C. speoken inf. 48,9; 2, 10 (N. speken); C. speoked') $3^{\text {rd }}$ sg. 96, 24 (N. speked); C. to speokene 74, 23; 98, 7 (N. to spekene); C. to speoke 74, 23 (N. speken); C. speoken 80,17 (N. speken); C. forzeouenesse 44, 23 (N. forgiuenesse); C. eoten Inf. 4, 7 (N. eten); C. beoren Inf. 4, 7 (N. beren); C. speoken Inf. 48, 9; 2, 10 (N. speken); C. forzeoted Imp. 34, 9 (N. uorzited). - The instances in which Cleo. has $e$ are: spekeð $3^{\text {rd }}$ pl. pres. 14,7 ; speken inf. 20,$22 ;$ bereð $2^{\text {nd }} \mathrm{pl}$. 30,7 ; to zeuen 68,13 (N. ziuen); speken 98,14 .

$\S$ 7. OE. $u / 0$-umlaut of $e$. This is found in all OE. dialects before liquids and labials; the spelling $e o$ is therefore usual both in Nero and Cleopatra. Ex. seouene 62,6; heouene 38, 16 etc.

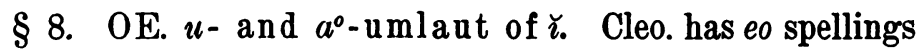
generally, $i$ in some words, Nero $i$ more frequently than $e o$.

Ex. C. neome 32, 7 (N. nime); C. neomed 46, 23 (N. nime); C. neomeð 46, 27 (N.nimeð); C. misneomeð 46, 27 (N. misnimeð); C. misneominge 46, 28 (N. misnimunge); C. neomed Imp. 100, 27 (N. nimeठ); C. unweote 8, 22 (N. unweote); C. ze cleoped 12, 27 (N. ze clepicઇ); C. cleopeð 58, 11 (N. cleopeð); C. icleoped 8, 25 (N. cleopede); C. witeð Imp. (N. witeð); C. N. witene 72, 1; C. N. wike 70, 7; 70, 6 .

§ 9. Palatal + e. K.G. has $e$ throughout (cp. Stodte $\S 29)$.

Cleo. has always $e$, Nero shows traces of the WS. treatment. Examples: C. zeue 30, 18 (N. ziue); C. zef me 38, 16; 26, 4 (N. zif); C. zeue me 28, 7 (N. zif); C. marhezeuen 30, 18 (N. morziuen); C. to zeuen 68,13 (N. ziuen); C. zеuеठ $3^{\text {rd }}$ sg. 60,22; 52,4 (N. ziued).

For the conj. 'if' Cleo. has always zef, which is also the invariable form in the Katherine Group; Nero has always zif. In the spelling of zelden, forget, zet Nero resembles Cleo. and has always $e$.

$\S 10$. Palatal $+o, u$. K. G. has $e o, o$ spellings but $u$ remains unchanged (cp. Stodte $\S 28$ ).

In this respect Cleo. differs from K. G. Ex. Cleo. zeung 56,$19 ; 6,14$ (N. zunge); C. zeunge 70,27; 56,7;52,3 (N. zunge); C. inzeong 52, 16 (N. inzong).

1) The eo.spelling in ME. is often analogically introduced, cp. the frequent instances of $e o$ before $k$. 
$\S 11$. $e+$ palatal $g$. As regards the treatment of $e$ in seggen (OE. secgan) Cleo. agrees with K. G. and differs from Nero.

Ex. C. segged 18,$19 ; 44,1$; seged 22,12 ; segge 66,3 ; segged 44,$24 ; 32,9 ; 22,7 ;$ seggen 24,$8 ; 8,2 ; 70,21 ; 20,22$ and frequent instances. - N. siggeð, sigge, siggen etc. always $i$. K. G. seggen, segen, segge, seggeð (cp. Stodte $\S 4$ a and Anm. 1).

$\S 12$. Syncope. K. G. $\S 38$ Anm. "Sehr beliebt ist die Syncopierung des Vokals in $\not \breve{e r}$ - (ae. päer) als erstes Glied von Kompositionen (cf. Morsb. me. Gr. § 69). prin (= perin), pron (= peron), prefter, prof."

Such and similar instances are common in Cleo. Ex. peorde 46, 37 (ter eorðe N.); prefter 8,15 (N. perefter); puttre 4, 17 (N. pe uttre); pinre 4, 15 (N. pe inre; poðеr 96,1 (N. pe oðer); prin 96, 7 (N.perinne); pruppe 100,2 (N. peruppe); peorðe 20,8(N.per eorðe).

$\S 13$. Certain Verbal Forms. (I) Infinitive in -in is used frequently in K. G. for verbs of various origin (cp. Stodte $\S 38$, P. 58). So also Cleopatra: changin 6,$18 ; 10,22$; lokin 56,7 ; lastin 64, 22; preisin 64, 22; totin 52,102; helpin 10,13; cnawin 92, 17; frofrin 94, 2; riwlin 4,12. - Nero has en.

(II) OE. moeg, meahte etc. St. Katherine: opt. sg. mahe frequently, mahen pres. plur., mahte usual pret. rarely mihte (cf. St. Katherine ed. Einenkel, E. E. T. S.); St. Juliana: mahen, mahte, tu maht, ne mahe ze etc. (cp. St. Juliana ed. Cockayne, E.E.T.S.); see also Stodte $\S \S 20,21$. - Cleo.: ne mazen 68,12 ; he maze 44,13 ; zе maze 70,$8 ; 26,6 ; 44,24 ; 44,9 ; 44,12 ; 44,5$; 16,$8 ; 62,8 ; 14,21$; machte 96,$7 ; 70,12$; machten 62,$16 ; 52,2$. Further one example of $i$ : michte 76,27 and a few with $u$ : muzen 62,$18 ;$ muze 84,$24 ; 98,10$; ze multen 8,17 . - Nero has $u$ in the present tense and $i$ or $u$ in the past: muwen 68,12 ; muwe 44,13; ze muwen 70, 8; 26, 6 etc.; muhten 8,17 ; muhte 96,7 ; nе muwe ze 98, 10 ; muzen $62,18$.

$\S 14$. Pronouns. Cleo. differs from Nero in having $h a$ very frequently for heo. Nero has heo always. K. G. has the two forms (cp. Stodte $\S 39 \mathrm{~b}$ "Neben $h \bar{e} \bar{o}$ erscheint $h \breve{a}$ ").

C. $h a$, N. heo 6,$25 ; 66,1 ; 64,27 ; 54,19 ; 54,25 ; 54,21$; 56,$1 ; 56,4 ; 56,3 ; 58,9 ; 58,8 ; 48,3 ; 48,16$ etc.

Liverpool, 13. Febr. 1905. Irene F. Williams. 